\title{
Konsumsi Nutrien Profil dan Metabolit Darah Induk Domba dengan Ransum Kaya Lemak Asal Minyak Nabati
}

Nutritional Intake, Blood Profile and Metabolites in Ewes Fed a Fat-Rich Diet of Vegetable Oils

L Khotijah*, Nurmiasih, D Diapari

Corresponding email:

lilis.khotijah@gmail.com

Departemen Ilmu Nutrisi dan Teknologi Pakan, Fakultas Peternakan, Institut Pertanian Bogor (Bogor Agricultural University/IPB University)

\section{ABSTRACT}

The aimed of this study was to evaluate the effect of vegetable fat supplementation in diet upon nutritional intake, the blood profile and metabolite of Garut ewes. Ten ewes with an initial weight of $24.87 \pm 4.02 \mathrm{~kg}$ were used in this experiment. The feed composition and ingredients used were based on the feed commonly used by Garut sheep breeders. The Sunflower seed oil and canola oil were used as source of vegetables oils. The feeding treatments were $\mathrm{R} 0$ (control = without the addition of vegetable oils) and R1 (the ration contains $5 \%$ vegetable oil). The data obtained were analyzed by T-Test. Nutrient intakes, including dry matter (DM), Crude Protein (CP), Crude Fat (CF), Crude Fiber (CF) and Nitrogen-Free Extract (NFE) were similar between dietary treatment of $5 \%$ vegetable oils supplementation and control. While Fat consumption was significantly higher $(\mathrm{p}<0.01)$ in vegetable oil supplemented group (R1) compare to control. The results of blood metabolites, including glucose and cholesterol and blood profile (hematocrit, hemoglobin, leukocytes, erythrocytes) analysis indicate that vegetable oil supplementation can be done without any significant effect. It was concluded that the ration containing 5 percent vegetable oil was not interfere the nutrients consumption, blood profile and metabolite levels of the postpartum ewes, so it can be applied by farmers.

Key words: blood profile, canola, fat, nutrient, sunflower seed, vegetable oil

\section{ABSTRAK}

Penelitian betujuan untuk mengevaluasi pengaruh ransum yang diperkaya lemak nabati terhadap konsumsi nutrien, profil dan metabolit darah induk domba pra kawin. Ternak yang digunakan adalah 10 ekor domba Garut betina dewasa, sudah pernah beranak dengan rataan bobot badan $24,87 \pm 4,02 \mathrm{~kg}$. Susunan ransum dan bahan pakan yang digunakan berdasarkan pakan yang biasa digunakan peternak domba Garut dan sumber minyak nabati berupa minyak biji bunga matahari dan kanola. Perlakuan yang diberikan yaitu R0 (Kontrol = tanpa penambahan minyak nabati) dan R1 (ransum mengandung 5\% minyak nabati). Peubah yang diukur meliputi: konsumsi bahan kering (BK), protein kasar (PK), lemak kasar (LK), serat kasar (SK), Beta-N, profil darah (hematokrit, hemoglobin, leukosit, eritrosit) dan metabolit darah (glukosa dan kolesterol). Data yang diperoleh diuji dengan T-test. Hasil penelitian menunjukkan bahwa ransum yang diperkaya dengan 5\% minyak nabati menghasilkan konsumsi BK, PK, SK dan Beta-N yang tidak berbeda dengan ransum kontrol, namun memberikan perbedaan yang sangat nyata $(\mathrm{p}<0,01)$ terhadap konsumsi lemak kasar. Kedua ransum perlakuan juga menghasilkan profil darah dan kadar metabolit darah yang tidak berbeda. Dapat disimpulkan bahwa ransum yang mengandung minyak nabati 5\% tidak mengganggu konsumsi, profil dan kadar metabolit darah induk domba dewasa pasca melahirkan, sehingga diharapkan dapat diterapkan di peternak.

Kata kunci: biji bunga matahari, domba betina, kanola, lemak minyak nabati, nutrien 


\section{PENDAHULUAN}

Domba Garut memiliki potensi genetik prolifik yaitu dapat menghasilkan lebih dari satu anak pada setiap kelahirannya. Sifat ini akan menguntungkan apabila dimanfaatkan secara optimal untuk mendukung peningkatan populasi ternak domba secara nasional. Potensi genetik prolifik tersebut akan optimal kemunculannya apabila didukung dengan kecukupan nutrien induk pada saat akan dikawinkan. Kecukupan nutrien induk pada saat akan dikawinkan,tersebut berkaitan dengan kesiapan dan kondisi tubuh induk yang harus dicapai, supaya dapat mendukung munculnya estrus dan keberhasilan reproduksi dalam program pembibitan menjadi hal yang penting diperhatikan dalam program pembibitan ternak.

Pada saat ini peternak domba, terutama di daerah Garut, sudah cukup pengetahuan dan kesadarannya dalam memberikan pakan tambahan pada ternak, diantaranya dengan memanfaatkan limbah industri pengolahan kedelai seperti kulit ari kedelai dan ampas tahu. Pemberian pakan tersebut untuk induk domba yang akan dikawinkan kembali diduga dapat mencukupi kebutuhan protein, namun masih perlu diperhatikan kadar energi yang juga dibutuhkan dalam fase reproduksi tersebut. Ampas tahu yang relatif cepat mengenyangkan, perlu dikombinasikan dengan sumber energi yang densitasnya tinggi, diantaranya penambahan minyak nabati

Minyak nabati, seperti minyak biji bunga matahari dan minyak kanola sebagai bahan pakan sumber energi, selain menyumbangkan energi, juga diharapkan dapat mensuplai asam lemak esensial seperti linoleat. Khotijah et al. (2014) menyatakan bahwa linoleat yang berasal dari minyak bunga matahari merupakan prekursor sintesa prostaglandin, sehingga dengan bertambahnya minyak dalam ransum akan mendukung ketersediaan prostaglandin untuk proses melisiskan corpus luteum, sehingga mempercepat timbulnya estrus. Ketersediaan hormon sangat dibutuhkan untuk kesiapan bereproduksi.

Menurut Wathes et al. (2007) pemberian pakan yang mengandung asam linoleat akan meningkatkan produksi hormon prostaglandin pada domba. Widiyanto et al. (2007) menjelaskan, suplementasi asam lemak tak jenuh mampu mengubah pola fermentasi dengan meningkatkan produksi asam propionat dan menurunkan nisbah asam asetat/propionat, sehingga terjadi peningkatan efisiensi energi. Minyak biji bunga matahari mengandung asam lemak tidak jenuh berupa asam oleat $26,19 \%$ dan asam linoleat $65,09 \%$ (Husna et al. 2012), sedangkan minyak kanola mengandung oleat (C18:1) 57,4\%, linoleat (C18:2) 17,3\%, dan linolenat (C18:3) 5,3\% (Maia et al. 2012). Penambahan minyak nabati sebagai sumber asam lemak untuk ransum domba betina sebelumnya dikaji oleh Pujiawati et al. (2018) dengan penggunaan minyak biji bunga matahari dan minyak flaxseed pada taraf $4 \%$ dalam konsentrat menghasilkan respon estrus, tingkat kebuntingan, jumlah embrio dan jumlah anak lebih baik dari kontrol. Masih perlu dikaji penggunaan jenis minyak lainnya untuk member alternatif sumber asam lemak yang bisa diterapkan di peternak, maka dalam penelitian ini dicoba penggunaan kanola.

Pada ruminansia tingginya kadar asam lemak tak jenuh atau sumber asam lemak esensial dalam pakan dikhawatirkan dapat mengganggu konsumsi pakan, yang secara tidak langsung dapat mempengaruhi kondisi ternak tesebut. Seperti yang dinyatakan Sudarman et al. (2008), bahwa pemberian pakan yang tinggi kandungan lemak dan energi pakan akan mempengaruhi tingkat konsumsi pakan, makin tinggi maka konsumsi pakan cenderung menurun. Penelitian bertujuan untuk mengevaluasi sejauh mana penambahan minyak nabati dalam pakan yang biasa diberikan peternak dapat digunakan, maka dievaluasi efeknya terhadap konsumsi nutrien profil darah dan kadar metabolit darah induk domba pra kawin.

\section{METODE}

\section{Ternak dan Ransum Percobaan}

Penelitian ini menggunakan 10 ekor domba betina yang sudah pernah melahirkan dengan rataan bobot badan $24,87 \pm 4,02 \mathrm{~kg}$. Bahan pakan yang digunakan rumput Brachiaria humidicola dan konsentrat dengan rasio pemberian 30:70 berdasarkan bahan kering. Bahan penyusun konsentrat merupakan bahan pakan yang sudah biasa diberikan peternak domba di daerah Garut, yaitu onggok, ampas tahu, limbah kulit kacang kedelai, garam, CaCO3, premix ditambah minyak nabati yang terdiri dari minyak biji bunga matahari dan minyak kanola. Pakan perlakuan yang diberikan yaitu R0 (Kontrol= tanpa penambahan minyak nabati) dan R1 (pakan mengandung 5\% minyak nabati). Pakan disusun berdasarkan NRC (2007). Komposisi bahan pakan dan nutrient pakan disajikan pada Tabel 1.

\section{Pemeliharaan dan Pengukuran Konsumsi Pakan}

Pemeliharaan dilakukan dalam kandang individu yang dilengkapi tempat pakan dan air minum, Pakan di berikan tiga kali sehari, air minum diberikan ad libitum. Konsumsi pakan (g ekor-1 hari ${ }^{-1}$ ) merupakan selisih antara pemberian pakan dengan sisa pakan yang diukur setiap hari. 
Tabel 1 Komposisi bahan pakan dan nutrien pakan perlakuan berdasarkan bahan kering

\begin{tabular}{|c|c|c|}
\hline \multirow{2}{*}{ Bahan Pakan } & \multicolumn{2}{|c|}{ Perlakuan } \\
\hline & RO & R1 \\
\hline Rumput Brachiaria humidicola & 30 & 30 \\
\hline Ampas tahu & 32 & 30 \\
\hline Onggok & 26 & 23,8 \\
\hline Kulit ari kedelai & 10,5 & 9,5 \\
\hline Minyak kanola & 0 & 4,7 \\
\hline Minyak biji bunga matahari & 0 & 0,5 \\
\hline Garam & 0,5 & 0,5 \\
\hline $\mathrm{CaCO} 3$ & 0,5 & 0,5 \\
\hline Premix & 0,5 & 0,5 \\
\hline \multicolumn{3}{|l|}{ Nutrien } \\
\hline Bahan kering & 45,37 & 47,40 \\
\hline Abu & 5,47 & 5,32 \\
\hline Protein kasar & 14,68 & 13,43 \\
\hline Lemak kasar & 2,69 & 8,70 \\
\hline Serat kasar & 22,53 & 22,07 \\
\hline Beta-N & 54,63 & 50,48 \\
\hline TDN* & 67,37 & 70,10 \\
\hline
\end{tabular}

Kadar nutrien total pakan penelitian diperoleh melalui perhitungan

hasil analisis bahan pakan; *) Perhitungan Wardeh (1981) R0

(Kontrol= tanpa penambahan minyak nabati) dan R1 (pakan mengandung 5\% minyak nabati)

\section{Pengambilan Sampel Darah}

Sampel darah diambil pada minggu ke-3 pemeliharaan, sebelum domba diberi makan. Darah diambil dari vena jugularis menggunakan spoit steril $5 \mathrm{ml}$, kemudian dimasukkan ke dalam tabung steril berisi antikoagulan EDTA. Sampel darah dibagi dua untuk keperluan analisis profil darah dan kadar metabolit darah (glukosa dan kolesterol).

\section{Pengamatan Profil Darah}

Profil darah yang diamati meliputi, kadar haemoglobin, jumlah butir darah merah (erythrosit), jumlah butir darah putih (leukosit) mengikuti prosedur Sastradiprajadja et al. (1989). Kadar Haemoglobin dianalisisi menggunakan metode Sahli (Harsh, 2013).

\section{Metabolit Darah}

Sampel darah disentrifuse dengan kecepatan 3000 rpm selama 15 menit untuk mendapatkan plasmanya. Kadar metabolit darah dianalisis dengan kit, kadar glukosa menggunakan reagen kit glukosa (Cat. No. 112191, reg. No. AKL20, 101, 803, 460) dan kolesterol dengan reagen kit kolesterol (Cat. No. 101592, reg No. AKL10, 101, 803, 466). Pembacaan kadar metabolit darah menggunakan spektrofotometer Genesys ${ }^{\circledR}$ 10S UV-Vis dengan panjang gelombang $500 \mathrm{~nm}$.

Kadar glukosa dihitung dengan menggunakan rumus sebagai berikut:

$$
\text { Glukosa }\left(\mathrm{mg} \mathrm{dL}^{-1}\right)=\frac{\text { absorbansi sampel }}{\text { absorbansi standar }} \times 100
$$

Kadar kolesterol dihitung dengan menggunakan rumus sebagai berikut:

$$
\text { Kolesterol }\left(\mathrm{mg} \mathrm{dL}^{-1}\right)=\frac{\text { absorbansi sampel }}{\text { absorbansi standar }} \times 200
$$

\section{Rancangan Percobaan dan Analisis Data}

Penelitian menggunakan rancangan acak lengkap 2 perlakuan 5 ulangan. Data yang diperoleh dianalisis dengan menggunakan T-Test. Peubah yang diamati meliputi konsumsi bahan kering, protein kasar, lemak kasar, serat kasar dan Beta-N, profil darah (hemoglobin, hematokrit, eritrosit, leukosit), serta metabolit darah yang terdiri dari kadar glukosa dan kolesterol.

\section{HASIL DAN PEMBAHASAN}

\section{Konsumsi Nutrien}

Rataan konsumsi bahan kering dan nutrien domba betina disajikan pada Tabel 2. Konsumsi bahan kering, protein kasar, serat kasar, dan Beta-N yang dihasilkan dari kedua perlakuan tidak ada perbedaan yang nyata, namun berbeda sangat nyata $(\mathrm{p}<0,01)$ untuk konsumsi lemak. Konsumsi lemak dari domba-domba yang diberi pakan mengandung $5 \%$ minyak nabati menghasilkan jumlah lemak yang dikonsumsi sangat nyata lebih tinggi dibanding yang mengkonsumsi pakan kontrol (tanpa minyak nabati).

Konsumsi bahan kering yang tidak dipengaruhi oleh tambahan minyak biji bunga matahari dan kanola sebagai sumber minyak nabati, menunjukkan bahwa penambahan minyak tersebut tidak mengganggu palatabilitas ransum. Hal ini sejalan dengan tingkat konsumsi energi yang digambarkan oleh Beta-N yang juga tidak berbeda nyata. Konsumsi bahan kering yang tidak berbeda walaupun ada peningkatan kadar lemak pakan disebabkan oleh karena kadar TDN (energi) pakan dibuat relatif sama. Menurut Pond et al. (1995) konsumsi bahan kering pakan dipengaruhi oleh bau, rasa, tekstur dan suhu. Hal ini menunjukkan bahwa

Tabel 2 Rataan konsumsi bahan kering dan nutrien domba betina

\begin{tabular}{lrr}
\hline \multirow{2}{*}{ Konsumsi } & \multicolumn{2}{c}{ Perlakuan } \\
\cline { 2 - 3 } & \multicolumn{2}{c}{ R0 ${\text { ( } \text { ekor }^{-1} \text { hari }^{-1} \text { ) }}^{\text {B }}$} \\
\cline { 2 - 3 } Bahan kering & $609,79 \pm 99,39$ & $707,25 \pm 60,24$ \\
Protein kasar & $92,29 \pm 16,43$ & $95,40 \pm 8,93$ \\
Lemak kasar & $16,83 \pm 2,90^{\mathrm{b}}$ & $62,64 \pm 4,77^{\text {a }}$ \\
Serat kasar & $138,25 \pm 23,41$ & $154,31 \pm 13,61$ \\
Beta-N & $330,00 \pm 51,88$ & $357,69 \pm 30,11$ \\
Superskrip huruf yang berbeda pada baris yang sama menyatakan \\
berbeda sangat nyata (p<0,01), \\
$\begin{array}{l}\text { R0 (Kontrol= tanpa penambahan } \\
\text { mengandung 5\% minyak nabati) }\end{array}$
\end{tabular}


penambahan minyak nabati $5 \%$ di dalam ransum tidak menimbulkan bau, merubah rasa, tekstur maupun suhu di dalam pakan sehingga tidak mempengaruhi palatabilitas pakan.

Jumlah bahan kering yang dikonsumsi domba induk sudah terpenuhi sesuai dengan NRC (2007), bahwa konsumsi bahan kering domba betina dengan bobot badan 20-30 kg adalah 530-700 g ekor-1 hari $^{-1}$. Hasil penelitian ini sejalan dengan Maia et al (2012), yang memberikan pakan diperkaya minyak kastor, minyak kanola dan minyak biji bunga matahari $30 \mathrm{~g} \mathrm{~kg}^{-1} \mathrm{BK}$, hasilnya tidak mempengaruhi konsumsi bahan kering.

Protein kasar, seratkasar dan Beta- $\mathrm{N}$ yang dikonsumsi domba induk juga tidak dipengaruhi penambahan minyak nabati sebanyak $5 \%$. Hal ini sejalan dengan konsumsi bahan kering. Secara keseluruhan jumlah protein, serat kasar dan Beta-N yang dikonsumsi sudah sesuai dengan NRC (2007), memberi gambaran bahwa pakan yang dibuat mampu memenuhi standar kebutuhan nutrient domba induk.

Konsumsi lemak kasar sangat nyata $(p<0,01)$ dipengaruhi oleh penambahan minyak nabati di dalam pakam sesuai pernyataan Haddad \& Younis (2004), bahwa konsumsi lemak kasar dapat meningkat sejalan dengan penambahan jumlah lemak dalam pakan. Konsumsi lemak kasar pada perlakuan pakan kontrol (R0) sebanyak 16,83 g ekor-1 $^{-1}$ ari ${ }^{-1}$ dan setelah diberikan penambahan minyak nabati $5 \%$ di dalam paakn (R1) konsumsi lemak kasar menjadi 62,64 g ekor ${ }^{-1}$ hari-1. Peningkatan konsumsi lemak kasar ini diharapkan akan bermanfaat dalam mendukung sintesa hormonal untuk domba betina yang akan dikawinkan, karena peningkatan konsumsi lemak secara tidak langsung akan menambah konsumsi asam lemak yang dapat berfungsi sebagai prekursor sintesa hormon reproduksi. Hess et al. (2005) menyatakan bahwa pada fase reproduksi ketersediaan nutrien ada hubungannya dengan pengaturan dan sintesis hormon.

\section{Profil dan Metabolit Darah}

Rataan profil, kadar glukosa dan kolesterol darah domba betina yang dihasilkan dari penelitian disajikan pada Tabel 3. Hasil penelitian menunjukkan bahwa tidak ada perbedaan yang nyata untuk kadar haemoglobin, hematokrit, jumlah sel darah merah dan jumlah leukosit yang dihasilkan dari kedua perlakuan yang diberikan. Hasil penelitian sejalan dengan penelitian Anggraeny (2013) yang memberikan pakan dengan kadar minyak biji bunga matahari $4 \%$ di dalam pakan domba betina pra kawin, tidak mempengaruhi kadar hemoglobin, hematokrit, jumlah sel darah merah dan sel darah putih. Secara keseluruhan profil darah yang dihasilkan berada pada kisaran normal seperti yang dinyatakan Schalm (2010).
Tabel 3 Profil darah dan kadar metabolit plasma domba betina

\begin{tabular}{|c|c|c|c|}
\hline \multirow{2}{*}{ Hematologi darah } & \multicolumn{2}{|c|}{ Perlakuan } & \multirow{2}{*}{$\begin{array}{c}\text { Normal } \\
\text { (Schalm, 2010) }\end{array}$} \\
\hline & RO & $\mathrm{R} 1$ & \\
\hline Hemoglobin ( $\mathrm{g} \mathrm{dl}^{-1}$ ) & $11,72 \pm 0,94$ & $12,08 \pm 1,17$ & $9-15$ \\
\hline Hematokrit (\%) & $29,80 \pm 1,43$ & $30,95 \pm 2,66$ & $27-45$ \\
\hline Eritrosit $\left(10^{6} \mathrm{~mm}^{-3}\right)$ & $10,78 \pm 1,28$ & $10,16 \pm 0,43$ & $9-15$ \\
\hline Leukosit $\left(10^{3} \mathrm{~mm}^{-3}\right)$ & $8,68 \pm 0,73$ & $8,47 \pm 0,33$ & $4-8$ \\
\hline Glukosa (mg dl-1) & $45,14 \pm 3,28$ & $44,57 \pm 2,28$ & $35-60^{*}$ \\
\hline Kolesterol (mg dl-1) & $51,46 \pm 15,34$ & $52,77 \pm 8,10$ & $50-140^{* *}$ \\
\hline
\end{tabular}

Pakan kontrol (R0) dengan pakan yang mengandung $5 \%$ minyak nabati (R1) tidak terdapat perbedaan terhadap rataan metabolit darah domba betina (Tabel 3). Kadar glukosa yang dihasilkan masih berada pada kisaran normal, sesuai Riis (1983), bahwa kadar glukosa domba pada kondisi sehat pada kisaran 35-60 $\mathrm{mg} \mathrm{dl}^{-1}$. Glukosa berfungsi sebagai sumber energi tercepat untuk dijadikan ATP baik bagi organ utama seperti otak dan sistem saraf maupun untuk organ yang lain yang perannya tak dapat digantikan oleh nutrien lain (Astuti et al. 2006). Glukosa merupakan substrat metabolisme utama yang dibutuhkan untuk reproduksi. Glukosa diperlukan dalam jumlah besar oleh beberapa jaringan spesifik termasuk otak, jaringan adiposa, otot, janin dan kelenjar susu (Riis 1983).

Sama halnya dengan glukosa, kadar kolesterol yang dihasilkan pada penelitian ini juga tidak dipengaruhi oleh penambahan minyak nabati 5\%. Nilai yang dihasilkan masih berada pada kisaran normal, sesuai Smith dan Mangkoewidjojo (1988), bahwa kisaran normal kolesterol domba antara 50-140 $\mathrm{mg} \mathrm{dl}^{-1}$. Menurut Khotijah et al. (2014) kadar kolesterol pada saat sebelum perkawinan dibutuhkan untuk sintesis hormon steroid yang berperan dalam persiapan estrus. Kadar kolesterol yang dihasilkan sejalan dengan penelitian Khotijah et al (2015) yang memberikan pakan mengandung $6 \%$ minyak nabati (minyak biji bunga matahari) bahwa tidak mempengaruhi kadar kolesterol di dalam darah pada saat sebelum perkawinan (kolesterol = 88,93 $\pm 20,68 \mathrm{mg} \mathrm{dl}^{-1}$ ). Kolesterol diperoleh dari pakan dan biosintesisnya yang terjadi pada organ tubuh seperti usus dan hati. Menurut Hardjopranjoto (1995), rendahnya kadar kolesterol dalam darah dapat menekan birahi dan ovulasi atau mengurangi jumlah sel telur yang diovulasikan.

Profil dan kadar metabolit darah domba tidak berbeda dan masih pada kisaran normal, menunjukkan hal yang positif bahwa penambahan minyak nabati sebesar $5 \%$ pada pakan domba betina tidak mengganggu proses pembentukan komponen darah dan penyerapan nutrien hasil metabolism, yang secara tidak langsung juga menunjukkan tingkat kesehatan/kondisi 
fisiologis ternak tidak terganggu. Hal ini sesuai dengan pernyataan Astuti et al. (2008), bahwa gambaran atau profil hematologi dan status metabolit darah merupakan salah satu indikator penentu kondisi fisiologi ternak.

\section{SIMPULAN}

Pemberian pakan mengandung 5\% minyak nabati pada domba betina pra kawin dapat dilakukan tanpa mengganggu konsumsi nutrien dan kondisi fisiologis ternak

\section{DAFTAR PUSTAKA}

Anggraeny A. 2013. Penambahan minyak biji bunga matahari terhadap profil darah domba Garut betina pada status faal berbeda [skripsi]. Bogor (ID): Institut Pertanian Bogor.

Astuti DA, Ekastuti DR, Marwah \& Suryani. 2006. Status nutrien dan gambaran darah domba lokal yang dipelihara di Hutan Pendidikan Gunung Walat Sukabumi. Prosiding Seminar Nasional Teknologi Peternakan dan Veteriner. Bogor (ID) : Balai Penelitian Ternak

Astuti DA, Ekastuti DR, Sugiarti Y \& Marwah. 2008. Profil darah dan nilai hematologi domba lokal yang dipelihara di Hutan Pendidikan Gunung Walat Sukabumi. Agripet. 8(2):1-8.

Haddad SG \& Younis HM. 2004. The effect of adding ruminally protected fat in fattening diets on nutrient intake, digestibility and growth performance of Awassi lambs. Animal Feed Science and Technology. 113:61-69.

Hardjopranjoto HS. 1995. Ilmu Kemajiran pada Ternak. Surabaya (ID): Airlangga University Pr.

Harsh M. 2013. Pathology Practical Book. Third Edition, Exercise 47: Haemoglobin Estimation 192-193. New Delhi (IN): Jaypee Brothers Medical Publishers

Hess BW, Lake SL, Scholljegerdes EJ, Weston TR, NayigihuguV, Molle JDC \& Moss GE. 2005. Nutritional controls of beef cow reproduction. Journal of Animal Science. 83: 90-106.

Husna N, Suryanto \& Purba D. 2012. Efek pelembab minyak biji bunga matahari dalam sediaan krim tangan. Journal of Pharmaceut Pharmacol.1(1): 63-69.

Khotijah L, Setiadi MA, Wiryawan KG \& Astuti DA .2015. Reproductive performance, cholesterol and progesterone status of garut ewes fed ration containing different levels of sun flower oil. Pakistan Journal of Nutrition 14(7): 388-391 DOI: 10.3923/pjn.2015.388.391

Pujiawati Y, Khotijah L, Sudarman A \& Wijayanti I. 2018. Effect of different ratio omega-3 and omega- 6 in total mix ration on productive performance, blood metabolites and estrous characteristic of ewes. Buletin Peternakan 42 (4): 295-300, Doi: 10.21059/buletinpeternak.v42i4.29254

Khotijah L, Zulihar R, Setiadi MA, Wiryawan KG \& Astuti DA. 2014. Suplementasi minyak bunga matahari (Helianthus annus) pada ransum pra kawin terhadap konsumsi nutrien dan karakteristik estrus domba garut. Jurnal Ilmu Ternak dan Veteriner. 19(1):9-16.

Maia M de O, Ivan ,Terreira EM, Olli CPN,Gentil A \& Vazpires GB. 2012. Intake, nutrient apparent digestibility and ruminal constituents of sheep fed diets with canola, sunflower or castor oils. Revista Brasileira Zootecnia 41(11):2350-2356.

[NRC] National Research Council. 2007. Nutrient Requirement of Sheep. Washington (US): National Academy Pr.
Pond WG, Church CD \& Pond KR. 1995. Basic Animal Nutrition and Feeding. Ontario (CN): John Willey and Sons.

Riis PM. 1983. Dynamic Biochemistry of Animal Production. New York (US):Amsterdam Elsevier.

Sastradipradja D \& Hartini S. 1989. Fisioligi Veteriner. Bogor (ID): Institut Pertanian Bogor.

Schalm OW. 2010. Schalm's Veterinary Hematology. 6th ed. Weiss DJ dan Wardrop KJ, editor. Iowa (US): WileyBlackwell

Smith JB \& Mangkuwidjojo S. 1988. Pemeliharaan, Pembiakan dan Penggunaan Hewan Percobaan di daerah Tropis. Jakarta (ID): UI Pr.

Sudarman A, Wiryawan KG \& Markhamah H. 2008. Penambahan sabunkalsium dari minyaklemuru dalam ransum: 1. Pengaruhnya terhadap tampilanproduksi domba. Media Peternakan.31(3):166171.

Wardeh MF. 1981. Models for estimating energy and protein utilization for feeds [disertasi]. Utah (US): Utah State University.

Wathes DC, Abayasekara DRE \& Aitken RJ. 2007. Polyunsaturated fatty acids in male and female reproduction. Biology of Reproduction 77:190-201.

Widiyanto, Soejono M, Bachrudin Z, Hartadi H \& Surahmanto. 2007. Pengaruh suplementasi minyak biji kapok terproteksi terhadap daya guna pakan serat secara in vitro. Journal of Indonesian Tropical Anima Agriculture.32(1):51-57. 